\title{
Manufacturing and Application of Complex Ferroalloys
}

\section{Vladimir Ivanovich Zhuchkov and Oleg Vadimovich Zayakin}

IMET UB RAS, Ekaterinburg, Russia

\section{Abstract}

The tightening of requirements for the quality of steel, a change in the composition of raw materials requires the release of more efficient ferroalloys of the new generation, suitable for progressive steel production processes. Such products include complex ferroalloys containing, in addition to iron, two or more functional elements. Complex ferroalloys should be created in the most favorable combination of components, contributing to the necessary effective impact on the quality of the metal being processed, with a high degree of assimilation of useful elements in it. Changes in the characteristics of complex ferroalloy, affecting the assimilation of target (basic) elements, should be carried out by regulating the composition and ratio of elements

Corresponding Author: Oleg Vadimovich Zayakin zferro@mail.ru

Received: 5 February 2019 Accepted: 6 March 2019 Published: 17 March 2019

Publishing services provided by Knowledge E

(c) Vladimir Ivanovich Zhuchkov and Oleg Vadimovich

Zayakin. This article is distributed under the terms of the Creative

Commons Attribution License, which permits unrestricted use and redistribution provided that the original author and source are credited.

Selection and Peer-review under the responsibility of the NIOKR-2018 Conference Committee. that can be included in almost any ferroalloy, since they are part of all steels and cast irons or they're required by the conditions of their smelting. Firstly, these elements should include silicon and manganese. Silicon can reduce the melting temperature, density, and melting time of ferroalloy in the liquid metal. For example, the addition of $1 \%$ silicon to low-carbon ferrochrome can reduce the melting point of the alloy by 8-9 degrees. Compositions of new complex ferroalloys of systems Fe-Si-Ca-Ba, Fe-Si-B, Fe-Si-Al-Nb, Fe-Si-Mn-V have been successfully tested and introduced into production.

Keywords: metallurgy, ferroalloy, melting, density, physical and chemical properties, steel

\section{Introduction}

Ferroalloy production is closely related to consumers of products - steel smelting [1, 2], cast iron [3] and non-ferrous metals. The volume of steel production determines the scale of production of ferroalloys.

In 2000 , the world produced 800 million tons of steel and 18 million tons of various ferroalloys, and in 2017, 1670 and $~ 40$ million tons, respectively.

Improving the quality of the metal has always been the most important task for world metallurgy. Quality improvement issues have become even more important recently. For the next 4-8 years around the world, including Russia, the tasks are set to increase the strength and ductility properties of steel by $50-60 \%$, some new, previously not existing 
requirements (for example, corrosion resistance of steel) have appeared, and besides, generally not by one property requirement, but on a complex of properties of metal.

Since one of the main methods of influencing properties of steel and cast iron traditionally remains the treatment of liquid metal with ferroalloys, the toughening of steel quality requirements leads to an increase in the output of alloyed grades and, consequently, to an increase in specific consumption of ferroalloys. The average global consumption of all ferroalloys per unit of steel in 2001 was $22.5 \mathrm{~kg} / \mathrm{t}$, and in 2015 already $\sim 30 \mathrm{~kg} / \mathrm{t}$.

Main products of ferroalloy plants are standard ferroalloys, which often don't have all the necessary service characteristics and are unsuitable for processing metal in the ladle, and the developing advanced technology of steelmaking has to adapt to the existing range of ferroalloys, standards that were not updated for 50 or more years. This leads to the technology complication, reduces productivity of steel production and product quality.

In addition, recently, the sources and markets of ferroalloy raw materials have changed, its quality and the content of leading elements have decreased, which makes it difficult or impossible to get ferroalloys by existing standards.

In this connection, there is the need to release more efficient ferroalloys of the new generation, suitable for new processes in the developing fields of ferrous and nonferrous metallurgy, smelted from new types of domestic ore raw materials.

First of all, these include the so-called complex or multicomponent ferroalloys containing, in addition to iron, two or more functional elements.

Complex ferroalloys (CF) should be created in the most favorable combination of components, contributing to the necessary effective impact on the quality of the metal being processed, with a high degree of assimilation of useful elements in it [4].

All elements included in the CF, can be divided into the following groups:

1. Target (basic) elements, whose content in the alloy is determined by the tasks of steel processing, its composition (these are $\mathrm{Cr}, \mathrm{Mn}, \mathrm{Nb}, \mathrm{V}$, etc.).

2. Elements that can be part of almost any ferroalloys, as they are in the composition of all steels and cast irons or these elements are required by conditions of their smelting (Fe, Mn, Si).

3. Elements that have a positive effect on steel and cast iron (modification, etc.) remaining in small quantities in the processed metal due to their low solubility or transition to slag (Ca, Ba, Mg). 
4. Harmful elements whose content in steel and ferroalloys is limited (S, P, non-ferrous metals).

By picking up target and related elements of the alloy its rational composition can be determined, that ensures high and stable assimilation of useful elements, rapid dissolution and their uniform distribution in the whole volume of the melt.

To determine the characteristics and rational composition of CF the scientific team of IMET UB RAS has developed a complex scheme which includes the following stages: - preliminary selection of elements in the alloy in accordance with the structure and specified properties of metals; - determination of the efficient ratio of elements based on the study of the physicochemical properties of alloys and characteristics of their interaction with the processed melt.

The physicochemical characteristics of the alloys that are responsible for the assimilation of elements in the liquid metal and its quality $[5,6]$ are studied: the temperature of the beginning and ending of melting; ferroalloy density; the kinetics of its oxidation; the number and shape of resulting non-metallic inclusions in the processed melt; thermal effect of CF interaction with iron-carbon melt; the duration of the ferroalloy melting and its thermal characteristics.

When creating a CF, it was taken into account that in its composition there should be, in addition to the target elements (group 1), also elements of group 2, which favorably influence performance characteristics of ferroalloys, contributing to an increase in the absorption of its components by steel.

These elements include silicon, the most widely used in CF. Suffice it to say that silicon is part of the world's most mass ferroalloy - ferrosilicon manganese [7, 8]. It currently produces about $1 / 3$ of the total assortment of ferroalloys (Figure 1) [9].

Silicon has a beneficial effect on such important characteristics of a ferroalloy as melting point, density, and time of swimming in the liquid metal.

We have conducted experiments on the effect of silicon on the characteristics of low carbon ferrochrome (Table 1) [10, 11].

Figure 2 shows the dependence of the density, temperature and melting time of ferrochrome on the content of silicon in it. These figures show that silicon has a significant impact on all of the alloys characteristics. Silicon exposure is especially significant in the range up to $10 \%$ (melting point can drop to $200^{\circ} \mathrm{C}$ ).

The effect of silicon on ferroalloys properties can be observed by other types of alloys. Table 2 shows the effect of silicon on the liquidus temperature and density of the Fe-Si-B complex alloy 


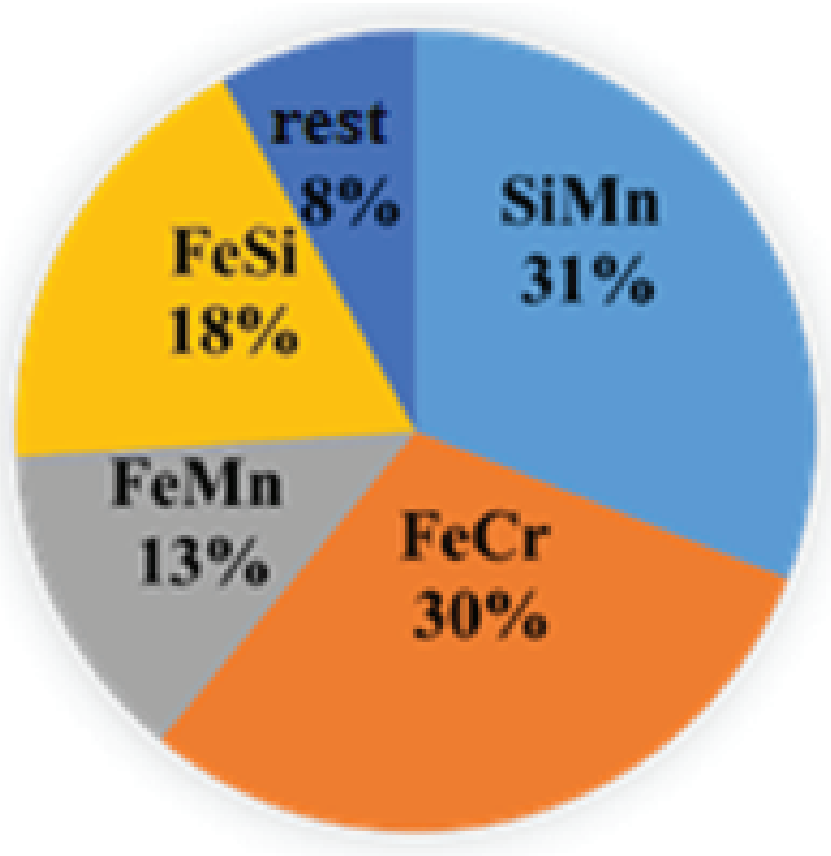

Figure 1: The world structure of ferroalloys production.

TABLE 1: Chemical composition of ferrochrome *, \%.

\begin{tabular}{|l|c|c|c|}
\hline Alloy №. & $\mathbf{C r}$ & $\mathbf{F e}$ & $\mathbf{S i}$ \\
\hline 1 & 64,6 & 34,8 & 0,5 \\
\hline 2 & 64,8 & 32,8 & 5,3 \\
\hline 3 & 57,8 & 32,1 & 10,0 \\
\hline 4 & 51,4 & 29,8 & 18,7 \\
\hline 5 & 46,2 & 27,2 & 26,5 \\
\hline 6 & 41,9 & 25,7 & 32,3 \\
\hline 7 & 35,6 & 22,3 & 42,0 \\
\hline 8 & 29,2 & 17,1 & 53,6 \\
\hline
\end{tabular}

TABLE 2: Composition and physico-chemical properties of ferrosilicoboron.

\begin{tabular}{|c|c|c|c|c|c|c|c|}
\hline \multicolumn{2}{|c|}{ Content,\%* } & \multirow{2}{*}{$\begin{array}{c}\text { T liquidus, } \\
{ }^{\circ} \mathrm{C}\end{array}$} & \multirow{2}{*}{$\begin{array}{c}\text { Density, } \\
\mathrm{kg} / \mathrm{m}^{3}\end{array}$} & \multicolumn{2}{|c|}{ Content,\%* } & \multirow{2}{*}{$\begin{array}{c}\text { T liquidus, } \\
{ }^{\circ} \mathrm{C}\end{array}$} & \multirow{2}{*}{$\begin{array}{c}\text { Density } \\
\mathrm{kg} / \mathrm{m}^{3}\end{array}$} \\
\hline$B$ & $\mathrm{Si}$ & & & $B$ & $\mathrm{Si}$ & & \\
\hline 1 & - & 1460 & 7800 & 5 & - & 1430 & 7550 \\
\hline 1 & 24,7 & 1395 & 6200 & 5 & 23,7 & 1418 & 6000 \\
\hline 1 & 44,5 & 1275 & 5520 & 5 & 42,7 & 1350 & 5340 \\
\hline 1 & 74,2 & 1258 & 3820 & 5 & 71,2 & 1273 & 3530 \\
\hline
\end{tabular}

The effect of silicon on the reduction of the melting temperature of refractory ferroalloys is quite significant. So, for ferrotungsten containing $70-80 \% \mathrm{~W}$, the melting start 

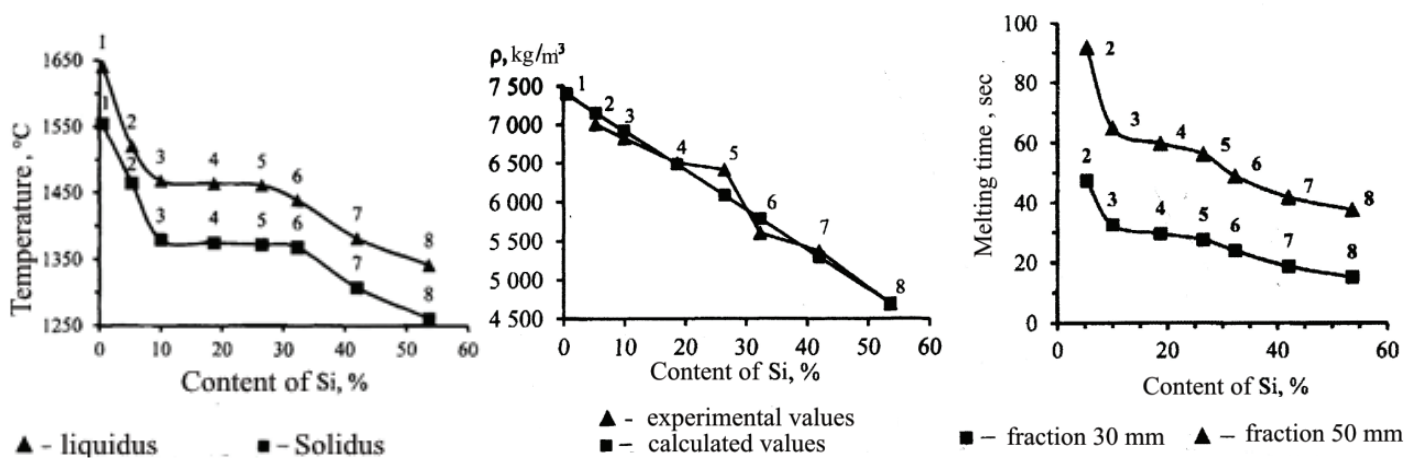

Figure 2: Dependence of characteristics of ferrochrome on the content of silicon in it. The numbers in the figure correspond to the numbers in Table 1. a - dependence of the melting point; $b$ - dependence of the density value; $\mathrm{c}$ - dependence of the melting time of ferroalloy in steel.

temperature is $\sim 2000^{\circ} \mathrm{C}$, the density is $15500 \mathrm{~kg} / \mathrm{m}^{3}$; when it contains $5 \% \mathrm{Si}$, the characteristics are improved to $1920^{\circ} \mathrm{C}$ and $13000 \mathrm{~kg} / \mathrm{m}^{3}$, and at $12 \%$ Si to $1720^{\circ} \mathrm{C}$ and 11000 $\mathrm{kg} / \mathrm{m3}$, respectively [12].

Manganese affects the melting point to a lesser extent than silicon. So for low-carbon ferrochrome $(0.1 \% \mathrm{C} ; 34-44 \% \mathrm{Cr})$ an increase in the manganese content from 12 to $31 \%$ reduced the liquidus temperature by only 48 degrees (from 1359 to $1311^{\circ} \mathrm{C}$ ).

It should be noted that lower quality ore raw materials can be used to produce complex ferroalloys than for smelting standard alloys, for example, substandard materials, production waste, poor and complex ores and concentrates. This is due to the fact that in the composition of the CF there are small concentrations of the leading elements in comparison to the composition of standard grades of ferroalloys (10-40, not 60-90\%). Due to the low price of unconventional raw materials, the possibility of its use and disposal, the cost of CF will be lower, and there appears a new raw material base of ferroalloy production.

The practice of CF production has shown that due to more flexible regulation of the technological parameters of smelting process, for example, the composition and melting point of the slag, softening and electrical resistance of the charge, it is possible to produce alloys in melting units with higher technical and economic indicators.

The negative side of complex ferroalloys is the loss of their universalism due to the increase in the number of components. At the same time, the use of CF allows to reduce the number of different types of ferroalloys used in the steel melt.

Practicing the developed method of designing the composition of CF using nontraditional raw materials, melting technologies were developed and various complex 
ferroalloys of several systems (Fe-Si-Ba-Ca, Fe-Si-B, Fe-Si-Al-Nb, Fe-Si -Ca-Mg, Fe-Si$\mathrm{V}-\mathrm{Ca}-\mathrm{Mn}, \mathrm{Fe}-\mathrm{Si}-\mathrm{Al}$ ) were obtained on an industrial scale. Patents for inventions were obtained for compositions and technology for producing several alloys $[13,14]$.

\section{Funding}

This work was supported by the Russian Federation Ministry of Education and Science (state research target for the Institute of Metallurgy, Ural Branch, Russian Academy of Sciences).

\section{References}

[1] Pariser H.H., Backeberg N.R., Masson O.C.M. et al. (2018). Changing nickel and chromium stainless steel markets. Market review by Heinz Pariser, in Infacon $X V$ : International Ferro-Alloys Congress, Edited by R.T. Jones \& P. den Hoed

[2] Cobb H.H. (2010). The History of Stainless Steels. ASM International. pp. 17-24

[3] Krüger P., Silva C.A., Batista Vieira C. et al. (2010). Relevant aspects related to production of iron nickel alloys (pig iron containing nickel) in mini blast furnaces, in Proceedings of The Twelfth International Ferroalloy Congress. V. I. Helsinki, Finland: Outotec Oyj.

[4] Zhuchkov V.I., Zayakin O.V. and Leontyev L.I. (2008). Main directions of processing of poor native chrome ore raw materials. Electrometallurgy, №5, pp. 18-21.

[5] Stroganov, A.I. (1980). Requirements for ferroalloys for deoxidation and alloying in Ferroalloy production: Collection of the Siberian Metallurgical Institute, 5-24. Novokuznetsk: Publishing Kuz. PI.

[6] Zhuchkov V.I., Zayakin O.V. and Mal'tsev Yu.B. (2001). Study of melting temperatures and density of ferroalloys containing nickel. Melts. № 1. pp. 7-9.

[7] Ringdalen E., Ostrovski O. and Gaal S. (2010). Ore properties in melting and reduction reactions in silicomanganese production in Proceedings of The Twelfth International Ferroalloy Congress. V. I. Helsinki, Finland: Outotec Oyj.

[8] Druinsky M.I. and Zhuchkov V.I. (1988). Production of complex Ferroalloys from mineral raw materials of Kazakhstan. Alma-Ata: Science.

[9] Boyarko G.Yu. and Khatkov V.Yu. (2018). Commodity Flows of Ferroalloys in Russia. Ferrous metals. № 3, pp. 60-63.

[10] Zhuchkov V.I., Andreev N.A., Zayakin O.V. et al. (2013). Composition and performance characteristics of chrome ferroalloys. Steel. №5, pp. 36-37. 
[11] Zhuchkov V.I., Andreev N.A. and Zayakin O.V. (2011). Study of the density of complex chromium-containing ferroalloys in Proceedings of the VI International Scientific and Practical Conference. Temirtau.

[12] Zayko V.P., Zhuchkov V.I., Drobyshevsky P.A. et al. (2005). Technology of tungstencontaining ferroalloys. Ekaterinburg: Ural Branch of RAS.

[13] Zhuchkov V.I., Sheshukov O.Yu. and Lozovaya E.Yu. (2005). The study of the physicochemical characteristics of ferroalloys and the design of their rational composition in Proceedings of conf. "Physical chemistry and technology in metallurgy". Ekaterinburg: Ural Branch of RAS.

[14] Zhuchkov V.I., Zayakin O.V., Leontyev L.I. et al. (2017) Physico-chemical characteristics of the preparation and use of complex boron-containing ferroalloys. University news. Ferrous metallurgy, Vol. 60, № 5, pp. 348-354. 